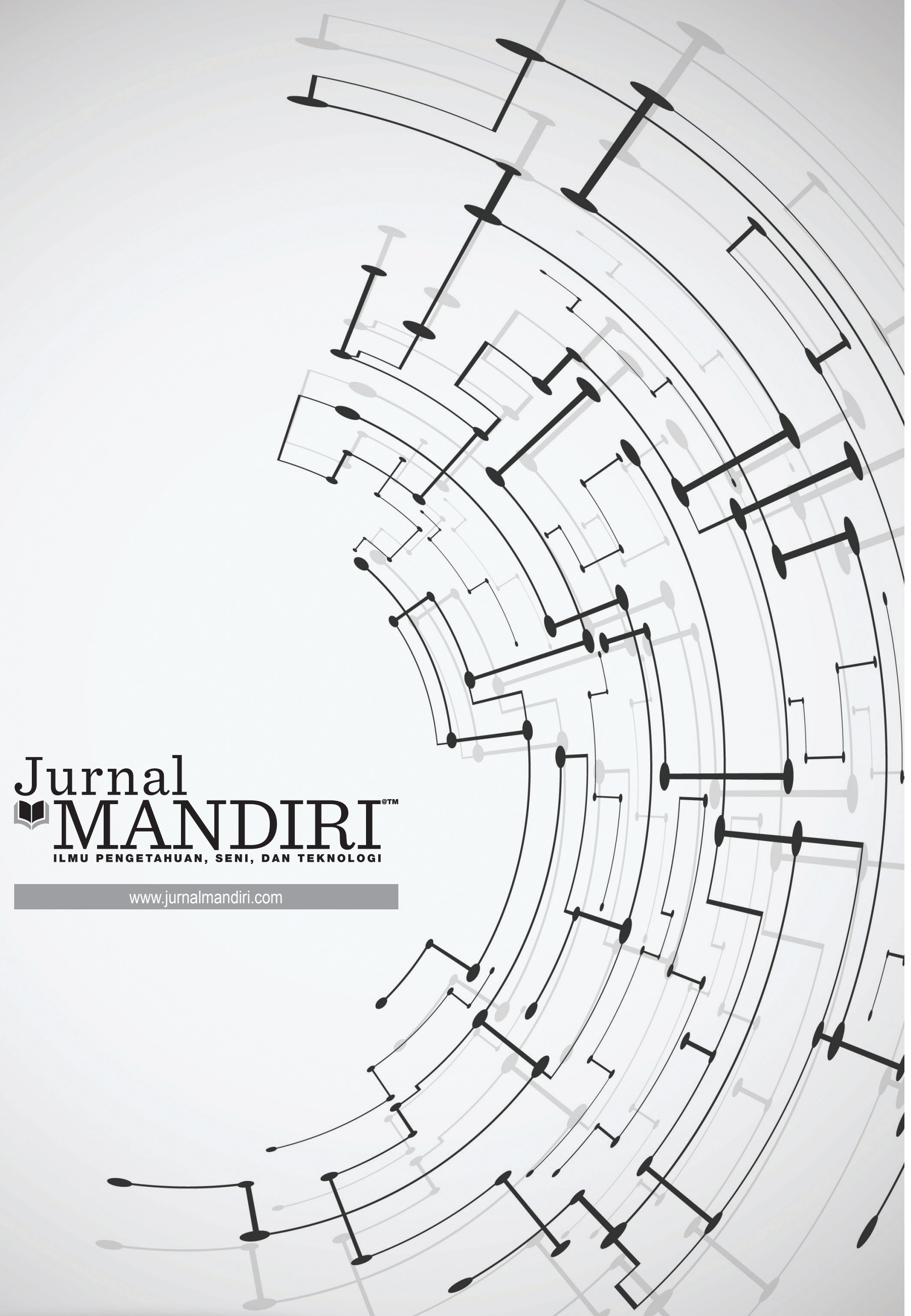


ISSN : 2580-3220, E-ISSN : 2580-4588

J. Mandiri., Vol. 1, No. 2, Desember 2017 (228 - 246)

(C2017 Lembaga Kajian Demokrasi

dan Pemberdayaan Masyarakat (LKD-PM)

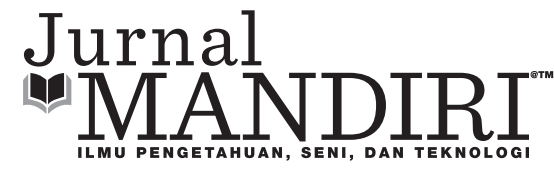

\title{
PREFENSI KONSUMEN TERHADAP PERMINTAAN MUR SPESIAL PADA PT. TRIDAYA EKA SEMESTA
}

\author{
Hamdi Mahmud \\ STIE YPN Karawang \\ hamdimahmud@gmail.com
}

\begin{abstract}
ABSTRAK
Penelitian ini dilakukan untuk mengetahui faktor-faktor apa saja yang dijadikan konsumen dalam mengambil keputusan menentukan permintaan terhadap mur spesial, untuk mengetahui pilihan mur spesial yang lebih diminati konsumen, untuk menganalisis tingkat sensitifitas masing-masing pilihan jika bobot faktor dinaikkan.

Secara umum, biasanya penilaian pelanggan terhadap satu produk adalah perbandingan antara benefit (manfaat) yang dirasakan atas penggunaan suatu produk dengan biaya yang harus dikeluarkan untuk mendapatkan produk tersebut. Untuk mendapatkan nilai (value) pelanggan yang sesuai dengan persepsi pelanggan, maka suatu perusahaan penyedia selalu harus mengikuti dengan menyediakan produk/jasa yang sesuai, karena nilai (value) pelanggan selalu berubah sepanjang waktu.

Teknik pengumpulan data dalam penelitian ini adalah kuisioner; membuat dan menyebar pertanyaan yang berhubungan dengan prefensi konsumen tehadap produk mur spesial dengan membandingkan faktor -faktor yang menurut responden lebih dominan antara satu faktor terhadap faktor lain. Responden diambil berdasarkan data personal yang dipilih oleh PT. Tridaya Eka Semesta bekerja sebagai konsumen atau pembeli (purchaser), quality control, gudang penerimaan barang, dan bagian produksi.

Analisa data dilakukan dengan menggunakan Anatical Hierarchy Process (AHP) Thomas Saaty, dan dikonstruksikan sebagai berikut: dengan menggunakan software (program pengolah data) expert choice. Hasil penelitian yang diperoleh adalah faktor bahan baku menjadi prioritas utama perusahaan perakit spare part sepeda motor dalam menentukan pilihan terhadap mur spesial. Ditunjukan dalam pendapatan bobot 37,50 \%, yang diikuti oleh kesesuaian spesifikasi teknis (ST) menjadi prioritas kedua dengan bobot $35,40 \%$ wujud fisik (WF) dengan bobot $14,20 \%$ menjadi prioritas ketiga kemasan (KM) dengan bobot 6,6 \% dan yang menjadi prioritas terendah adalah waktu pengiriman (WK) dengan bobot 6,2 \%. Tingkat konsistensi responden (ICR) adalah sebesar $4 \%$, maka penilaian atas pembobotan tersebut dianggap konsisten karena angka yang ditunjukan mensyaratkan di bawah $10 \%$.

Perbandingan antara dua merek yang menjadi pemasok mur spesial, yaitu Tridaya dan Inter. Terlihat bahwa Tridaya mampu memenangkan persaingan dengan bobot sebesar 75,1 \% sedangkan kompetitor yakni Inter menempati urutan berikutnya dengan bobot $24,9 \%$.

Analisis sensitifitas adalah faktor bahan baku jika dinaikkan menjadi $75 \%$ maka bobot pilihan terhadap mur spesial Tridaya berubah dari 75,1 \% menjadi 74,7 \% (menurun sebesar 0,4 \%). Jika faktor wujud fisik dinaikkan menjadi $50 \%$ maka bobot pilihan terhadap mur spesial Tridaya berubah dari
\end{abstract}


75,1 \% menjadi 75,3 \% (naik sebesar 0,2 \%). Jika faktor kemasan dinaikkan menjadi $40 \%$ maka bobot pilihan terhadap mur spesial Tridaya berubah dari 75,1 \% menjadi 74,6 \% (menurun menjadi 0,5\%). Sedangkan jika faktor waktu pengiriman dinaikkan menjadi $30 \%$ maka bobot pilihan terhadap mur spesial Tridaya berubah dari 75,1 \% menjadi 75,8 \% (akan naik sebesar 0,7 \%).

Kata Kunci: Prefensi, Konsumen, Permintaan, dan Mur Spesial

\section{PENDAHULUAN}

\section{Latar Belakang}

Fluktuasi market share dalam menilai berkembang atau tidaknya sebuah perusahaan, ditemukan berbagai hal yang mempengaruhi tingkat permintaan produk dan jasa yang dihasilkan. Naik atau turunnya jumlah permintaan terhadap hasil produksi, akan berpengaruh besar terhadap keuntungan perusahaan dan berbanding lurus dengan kemampuan perusahaan untuk dapat memenuhi kewajibannya dan ini menjadi indikator terhadap maju mundurnya perusahaan. Di saat persaingan bisnis yang sangat tajam, terjadinya pasar global, makin selektifnya konsumen, para manajer menyadari bahwa faktor-faktor terkecil apapun berpengaruh terhadap kriteria-kriteria yang digunakan sebagai dasar pertimbangan dalam mencapai tujuan.

Harga dan kualitas produk yang dihasilkan sebuah perusahaan, merupakan keberhasilan menejemen produksi perusahaan tersebut dalam memproses produknya. Perusahaan yang mengedepankan kualitas produk akan dapat memberikan nilai tambah produk yang dihasilkan disamping biaya produksi produk tersebut. Produk berkualitas baik akan lebih diminati oleh konsumen dibanding produk yang sama, harga sama dan kualitas lebih baik. Nilai tambah yang didapatkan konsumen akan membuat konsumen puas dan setelah mereka puas akan meningkatkan omzet penjualan. Seiring dengan meningkatnya penjualan maka diharapkan perusahaan akan mendapatkan laba yang lebih pula.

Pada uraian di atas dapat kita lihat betapa peranan harga dan kualitas produk merupakan hal yang tidak dapat diabaikan oleh perusahaan dalam menetapkan besarnya nilai yang akan diberikan oleh produsen kepada konsumen. Sama halnya yang dilakukan oleh PT. Tridaya Eka Semesta. Selain harga, kualitas produk yang baik diharapkan dapat memberi nilai lebih kepada konsumen dibanding dengan pesaing produk sejenis. Perusahaan memandang bahwa semakin murah harga dan semakin baik kualitas produk yang dihasilkan oleh perusahaan, maka konsumen akan merasa puas dan percaya pada perusahaan dengan memberikan order lebih, order perusahaan terus meningkat yang akhirnya akan meningkatkan laba perusahaan.

Untuk menghasilkan produk yang berkualitas, maka perusahaan harus memperhatikan bahan baku yang diolah harus memenuhi syarat teknis dan kualitas, karena hasil produksi akan baik jika bahan bakunya juga baik. PT. Tridaya Eka Semesta sangat selektif dalam memilih bahan baku yang dipakai/digunakan, jika tidak sesuai dengan standar teknis maka bahan baku ditolak dan akan dikembalikan kepada pemasoknya.

PT. Tridaya Eka Semesta dalam mencapai target-target penjualan yang diharapkan membuat suatu sistem pengendalian produk yang akan dijual agar produk-produk tersebut diterima oleh konsumen hanya produk yang baik saja. Aktualisasi yang terjadi sekarang adalah karena masih sering terjadi produk-produk yang ditolak (Not Good), sehingga target yang diharapkan belum tercapai oleh PT. Tridaya Eka Semesta

\section{RUMUSAN MASALAH}

1. Faktor-faktor apa saja yang dijadikan konsumen dalam mengambil keputusan me- 
nentukan permintaan terhadap mur spesial?

2. Pilihan mur spesial mana yang lebih diminati konsumen?

3. Bagaimana tingkat sentivity analisis masing-masing pilihan jika bobot faktor dinaikkan?

\section{TUJUAN PENELITIAN}

Sesuai dengan rumusan masalah yang ada, oleh karena itu penelitian ini bertujuan untuk

1. Mengetahui faktor-faktor apa saja yang dijadikan konsumen dalam mengambil keputusan untuk menentukan permintaan terhadap mur spesial.

2. Mengetahui pilihan mur spesial yang lebih diminati konsumen.

3. Menanalisis tingkat sentivity masing-masing pilihan jika bobot faktor dinaikkan.

\section{KAJIAN TEORI}

\section{Pengertian dan Konsep Inti Pemasaran}

Pada dasarnya pemasaran merupakan suatu proses sosial dan manajerial di mana individu dan kelompok mendapatkan apa yang mereka butuhkan dan inginkan melalui penciptaan dan pertukaran produk dan nilai dengan yang lain (Kotler dan Armstrong, 2001:6). The American Marketing Association (Kotler, 2003:6; Hollenson, 2003:9; Czinkota dan Kotabe, 2001:3) merumuskan definisi pemasaran yang lebih menekankan pada proses manajerial yaitu proses perencanaan dan penetapan konsepsi, penetapan harga, promosi dan distribusi gagasan, barang dan jasa untuk menciptakan pertukaran yang memuaskan tujuan individu dan organisasi.

Dalam hal ini pemasaran melibatkan sejumlah fungsi manajerial yang saling berhubungan dalam suatu proses manajemen, yaitu analysis, planning, implementation, dan control (Kotler dan Armstrong, 2001:69; Hollenson, 2003:6-7). Kegiatan pemasaran dapat diarahkan kepada konsumen akhir dan juga kepada industri (Czinkota dan Kotabe, 2001:8-9;
Sucherly, 1996:27). Perusahaan yang mengarahkan kegiatan pemasarannya ke konsumen akhir termasuk dalam kegiatan pemasaran produk konsumsi, produk yang dipasarkan merupakan produk konsumsi dan pasarnya disebut pasar konsumen. Sedangkan perusahaan yang mengarahkan kegiatan pemasarannya ke indusri termasuk dalam kegiatan pemasaran produk industri, produk yang dipasarkan merupakan produk industri dan pasarnya disebut pasar industri atau pasar bisnis. Pemasaran produk konsumsi dan pemasaran produk industri memiliki karakteristik yang berbeda, baik dilihat dari sifat produk maupun perilaku pembelinya. Pemasaran produk konsumsi umumnya dilakukan oleh perusahaan yang bergerak di sektor hilir. Sedangkan pemasaran produk industri umumnya dilakukan oleh perusahaan yang bergerak di sektor hulu.

Terdapat sejumlah konsep inti yang terkandung dalam pemasaran. Mempelajari konsep inti pemasaran akan sangat membantu dalam memahami hakekat pemasaran. Kotler (2003:612) mengidentifikasi konsep inti pemasaran itu, meliputi:

1. Target markets and segmentation. Segmentasi berkaitan dengan pengelompokan pasar yang menuntut bauran pemasaran yang berbeda. Segmen pasar ini dapat diidentifikasi berdasarkan aspek demographic, psychographic dan perilaku konsumen. Perusahaan kemudian memilih dan menetapkan segmen pasar yang akan dilayani sebagai pasar sasaran.

2. Marketplace, marketspace and metamarket. Marketplace bersifat fisik seperti seseorang berbelanja di suatu toko. Berbeda dengan marketplace, marketspace bersifat digital seperti seseorang berbelanja melalui internet. Adapun metamarket bersifat komplementer dari barang dan jasa berbagai industri yang relevan seperti automobile metamarkets, terdiri dari: pabrik mobil, dealer mobil, lembaga keuangan, perusahaan asuransi, dan lainnya. 
3. Marketers and prospects. Marketer adalah seseorang atau organisasi yang berusaha mendapatkan suatu respons (perhatian, pilihan dan pembelian) dari pihak lain atau prospect.

4. Need, wants and demand. Marketer harus berusaha memahami kebutuhan, keinginan dan permintaan pasar sasaran. Kebutuhan berkaitan dengan sesuatu yang harus atau menuntut pemenuhan. Manusia senantiasa dihadapkan pada masalah kebutuhan ini; setidak-tidaknya untuk kelangsungan hidupnya, berinteraksi, dan berkembang. Untuk kelangsungan hidupnya, manusia membutuhkan makanan, pakaian, rumah, dan lainnya. Kebutuhan berbeda dengan keinginan walaupun setiap keinginan manusia senantiasa didasarkan atau diturunkan dari kebutuhannya. Keinginan seseorang lebih banyak dipengaruhi oleh latar belakang pengalaman, kebudayaan, pendidikan, geografis, demografis, dan lainnya. Keinginan ditunjukkan oleh pilihan, seperti dalam hal makanan seseorang menginginkan roti dan yang lain menginginkan nasi. Suatu keinginan yang didukung oleh daya beli akan melahirkan permintaan. Seseorang yang menginginkan roti dan memiliki daya beli atau kemampuan untuk mendapatkannya maka orang itu akan membeli roti. Jadi permintaan seseorang atas suatu produk tekait dengan kebutuhan dan keinginan tentang produk itu yang didukung oleh kemampuan untuk mendapatkannya atau daya belinya.

5. Product, offering and brand. Produk berkaitan dengan nilai yaitu seperangkat manfaat yang ditawarkan kepada konsumen untuk memuaskan kebutuhannya.

6. Value and satisfaction. Kesesuaian antara kinerja produk dengan tuntutan konsumen akan membentuk kepuasan bagi konsumen yang bersangkutan. Dalam hal ini, kepuasan konsumen melibatkan komponen kinerja produk yang dibelinya dan tuntutan- nya atau harapannya atas produk itu. Tingkat kepuasan konsumen tergantung pada kesesuaian antara kedua komponen itu. Kepuasan dapat juga dikaji dari nilai konsumen berupa kesesuaian manfaat yang diperoleh konsumen dari suatu produk yang dibelinya dengan biaya atau pengorbanan yang dikeluarkan untuk memperoleh produk itu. Manfaat yang dirasakan konsumen berupa manfaat fungsional dan manfaat emosional. Sedangkan biaya yang dikeluarkan berupa uang, energi, waktu, dan mental. Agar dapat menciptakan nilai konsumen yang tinggi maka perusahaan atau produsen harus mampu memberikan manfaat yang lebih besar dari suatu produk yang ditawarkannya dibandingkan dengan biaya yang dikeluarkan konsumen untuk memperoleh produk itu.

7. Exchange and transactions. Pertukaran merupakan proses mendapatkan suatu produk dari pihak tertentu melalui penawaran. Terdapat lima kondisi atau syarat terjadinya pertukaran, yaitu: sekurang-kurangnya terdapat dua pihak, masing-masing pihak memiliki sesuatu yang bernilai bagi pihak lain, masing-masing pihak kapabel dalam berkomunikasi, masing-masing pihak bebas menerima atau menolak penawaran pertukaran dan masing-masing pihak saling mempercayai. Dalam pertukaran kedua pihak bernegosiasi untuk mencapai kesepakatan. Jika terjadi kesepakatan berarti terjadi transaksi. Dalam hal ini transaksi merupakan suatu pertukaran nilai antara dua pihak atau lebih, melibatkan waktu dan tempat.

8. Relationships and networks. Relationship marketing bertujuan untuk membangun hubungan yang saling memuaskan dalam jangka panjang dengan konsumen, pemasok, distributor, dan lainnya. Ini penting untuk meningkatkan dan memelihara bisnisnya dalam jangka panjang. Outcome dari relationship marketing berupa suatu 
jaringan pemasaran antara perusahaan dengan stakeholder-nya (konsumen, karyawan, pemasok, distributor, dan lainnya).

9. Marketing channels. Untuk mencapai pasar sasaran, marketer menggunakan tiga jenis saluran pemasaran, yaitu: pertama, cummunication channels yaitu menyampaikan dan menerima pesan kepada dan dari pasar sasaran. Kedua, distribution channels yaitu menyampaikan produk atau jasa kepada pembeli. Ketiga, service channels yaitu menyelenggarakan transaksi dengan pembeli potensial yang melibatkan warehouse, perusahaan transportasi, bank dan perusahaan asuransi untuk memfasilitasi transaksi.

10. Supply chain. Menggambarkan rentang saluran yang lebih panjang mulai dari bahan baku, produk akhir sampai ke pembeli akhir. Supply chain ini menggambarkan suatu sistem penyampaian nilai.

11. Competition. Mencakup seluruh pesaing aktual dan potensial. Terdapat empat level persaingan yaitu brand competition, industry competition, form competition, dan generic competition.

12. Marketing environment. Terdiri dari lingkungan tugas mencakup perusahaan, pemasok, distributor, konsumen, dan lingkungan yang lebih luas mencakup lingkungan demografi, lingkungan ekonomi, lingkungan alam, lingkungan teknologi, lingkungan politik-legal, dan lingkungan sosial-budaya. Lingkungan yang lebih luas terdiri dari kekuatan yang memiliki pengaruh pada pelaku dalam lingkungan tugas.

13. Marketing program. Tugas marketer adalah mengembangkan suatu program pemasaran atau rencana untuk mencapai tujuan perusahaan. Dalam hal ini, bauran pemasaran merupakan seperangkat alat yang digunakan perusahaan untuk mencapai tujuan pemasarannya dalam suatu pasar sasaran. Pada dasarnya alat-alat dalam bauran pemasaran itu terdiri dari produk, harga, distribusi, dan promosi.

\section{Orentasi Perusahaan Dalam Pasar}

Sejumlah philosophy atau orientasi perusahaan dapat dipilih dan digunakan dalam mencapai tujuan pemasaran. Philosophy atau orientasi perusahaan yang dipilih dijadikan pedoman seluruh kegiatan pemasaran. Kotler (2003:1217) mengemukakan enam orientasi perusahaan dalam kegiatan pemasaran, yaitu: the production concept, the product concept, the selling concept, the marketing concept, the customer concept, dan the societal marketing concept.

Sedangkan Hollensen (2003:9-14) mengelompokkan ke dalam dua philosophy atau orientasi perusahaan, yaitu the transactional marketing concept dan the relationship marketing concept. Pilihan atas satu atau beberapa philosophy atau orientasi perusahaan didasarkan pada kondisi yang ada dan menjadi syarat berlakunya philosophy atau orientasi perusahaan itu.

The production concept menyatakan bahwa konsumen akan menyukai produk yang tersedia di banyak tempat dan murah harganya. Perusahaan atau produsen berorientasi pada produksi dengan memusatkan perhatian pada upaya mencapai tingkat efisiensi produksi yang tinggi dan perluasan distribusi.

The product concept menyatakan bahwa konsumen menyukai produk yang menawarkan mutu, kinerja, dan pelengkap inovatif yang terbaik. Perusahaan atau produsen berorientasi pada produk dengan memusatkan perhatian pada upaya untuk menghasilkan produk yang bermutu serta secara terus-menerus menyempurnakannya.

The selling concept menyatakan bahwa konsumen, jika diabaikan, biasanya tidak akan membeli produk dalam jumlah yang banyak. Oleh karena itu, perusahaan atau produsen harus melakukan upaya penjualan dan promosi yang gencar.

The marketing concept menyatakan bahwa kunci untuk meraih tujuan perusahaan adalah menjadi lebih efektif daripada pesaing dengan memadukan kegiatan pemasaran dalam menciptakan dan memuaskan kebutuhan dan ke- 
inginan pasar sasaran. Menurut Winer (2004:6) the marketing concept ini paling banyak digunakan dalam kegiatan pemasaran.

The customer concept menyatakan bahwa perusahaan mengharapkan untuk mencapai pertumbuhan yang menguntungkan dengan merebut pangsa yang lebih besar dari setiap pengeluaran konsumen, membangun loyalitas konsumen yang tinggi dan memfokuskan pada nilai konsumen.

The societal marketing concept menyatakan bahwa tugas perusahaan atau produsen adalah menentukan kebutuhan, keinginan dan kepentingan pasar sasaran, serta memberikan kepuasan secara efektif dan efisien daripada pesaing dengan mempertahankan dan meningkatkan tanggung jawab sosial kepada konsumen dan masyarakat.

Hollenson (2003:6-7) mengemukakan bahwa pencapaian tujuan pemasaran yang bertumpu pada perencanaan dan pelaksanaaan unsur bauran pemasaran bersifat tradisional. Ini dikarenakan fokus utama dari program pemasarannya yaitu pada transaksi atau pembelian oleh konsumen tanpa memperhatikan apakah konsumen lama atau baru. The transactional marketing concept ini didasarkan pada tiga asumsi, yaitu:

1) terdapat sejumlah besar konsumen potensial,

2) konsumen dan kebutuhannya relatif homogen, dan

3) mudah mengganti konsumen yang ke luar dengan yang baru.

Berbeda dengan the transactional marketing concept, the relationship marketing concept berupaya melibatkan dan mengintegrasikan konsumen, pemasok, dan pihak lainnya dalam suatu jaringan untuk kepentingan aktivitas pemasaran dan pengembangan perusahaan. Relationship merupakan aset penting yang menentukan kelangsungan atau masa depan perusahaan.

Pemasaran tidak hanya sekadar menyampaikan produk dari tangan produsen ke tangan konsumen, tetapi pemasaran pun memperhatikan apakah kebutuhan dan keinginan konsumen terpenuhi, apakah konsumen puas terhadap produk tersebut, dan apakah konsumen akan melakukan pembelian ulang dan menjadi loyal terhadap produk atau merek tersebut.

Kotler \& Keller (2006:25) mengungkapkan pula bahwa: "Suatu perusahaan berhasil menawarkan produk/jasa kepada pelanggan apabila mampu memberikan nilai dan kepuasan (value and satisfaction)." Nilai (value) adalah perkiraan konsumen atas seluruh kemampuan produk untuk memuaskan kebutuhannya."

Secara garis besarnya, nilai pelanggan adalah perbandingan antara benefit (manfaat) yang dirasakan terhadap suatu produk dengan biaya yang harus dikeluarkan untuk mendapatkan produk tersebut. Untuk mendapatkan nilai pelanggan yang sesuai dengan persepsi pelanggan, maka suatu perusahaan harus selalu mengikutinya dengan menyediakan produk/ jasa yang sesuai, karena nilai pelanggan selalu berubah sepanjang waktu.

Menurut Kotler \& Keller (2006 : 136), 'total customer satisfaction" adalah "menciptakan pelanggan". Artinya, bahwa untuk dapat mempertahankan kelangsungan hidupnya, sebuah perusahaan harus memiliki konsumen yang merasa suka dan puas terhadap produk yang tawarkan.

Pada kenyataannya, menciptakan pelanggan tersebut tidaklah mudah. Perusahaan membutuhkan produk yang memiliki nilai yang sesuai dengan persepsi nilai pelanggan yang berlaku. Selain itu perusahaan menghadapi tantangan tersendiri dalam menghadapi konsumennya, karena pada saat ini konsumen dapat lebih leluasa memilih produk, merek, dan produsen yang sesuai dengan kebutuhan dan keinginannya. Untuk itu perusahaan saling berlomba memberikan nilai tertinggi bagi konsumen, karena konsumen menginginkan nilai maksimum dengan dibatasi oleh biaya pencarian, keterbatasan pengetahuan, mobilitas, dan penghasilan. Semakin besar manfaat yang di- 
berikan dibandingkan dengan harganya, maka semakin besar nilai yang diperoleh pelanggan terhadap produk tersebut.

\section{Nilai Jasa}

Hoffman dan Batteson mengidentifikasikan nilai pelanggan total ke dalam empat nilai yang diterima, yaitu nilai produk yang merupakan penilaian pelanggan terhadap produk. Kedua, nilai pelayanan yang merupakan penilaian yang diberikan pelanggan terhadap pelayanan. Ketiga, nilai karyawan yang diberikan berdasarkan penilaian terhadap pelayanan karyawan. Dan yang keempat adalah nilai citra, yang penilaiannya dilakukan oleh konsumen terhadap pelayanan atau penyedia jasa.

Total biaya pelanggan yang diungkapkan Hoffman dan Batteson di atas, diidentifikasikan ke dalam empat jenis biaya yang dikeluarkan pelanggan, yaitu: Pertama, biaya moneter adalah harga aktual yang harus dibayar pelanggan untuk mendapatkan sebuah produk. Kedua, biaya waktu yang merupakan waktu yang dihabiskan untuk memperoleh produk. Ketiga, biaya energi adalah energi yang dikeluarkan untuk memperoleh produk tersebut. Dan yang keempat, biaya psiskis yang merupakan energi mental yang dikeluarkan pelanggan untuk memperoleh produk tersebut.

Menurut Brady (1999), sasaran konsumsi pelanggan biasanya adalah: Sasaran nilai pelanggan biasanya adalah untuk memperoleh benefit/konsekuensi positif yaitu nilai penggunaan dan nilai kepemilikan. Nilai penggunaan meliputi fungsional benefit, setelah penggunaan produk mereka menerima benefit, misalnya efisiensi waktu, menghilangkan rasa haus, hiburan, mudah dibersihkan, awet, cepat saji, enak, dan lain-lain. Nilai kepemilikan adalah irasional benefit yang merupakan komponen yang menyebabkan kebanggaan jika memiliki, karena dalam produk terkandung simbolik penting harga diri, keindahan kualitas.

Diungkapkan pula oleh Hoffman dan Betteson (1997:154) bahwa, "Buyers perceptions of value represent a trade-off between the perceived benefits of the service to the purchased and the perceived sacrifice in terms of the cost to be paid." Artinya yaitu persepsi pembeli terhadap nilai menggambarkan sebuah perbandingan antara manfaat dari pelayanan yang dibeli dengan pengorbanan yang dirasakan dalam hubungannya dengan biaya yang dikeluarkan.

Kotler \& Keller (2006:134) menyatakan bahwa pemasar dapat meningkatkan nilai tawaran pelanggan dengan beberapa cara, yaitu:

a. Meningkatkan manfaat;

b. Mengurangi biaya;

c. Meningkatkan manfaat dan mengurangi biaya;

d. Meningkatkan manfaat lebih besar dari pada kenaikan biaya;

e. Mengurangi manfaat lebih kecil dari pada pengurangan biaya.

\section{Produk, Kualitas Produk, dan Peengendalian Kualitas Produk}

Produk sebagai hasil produksi pada usaha jasa dibagi berdasarkan:

a. Konsumen membeli kebutuhannya ditentukan oleh ketertarikan terhadap kualitas produk

b. Konsumen memilih merek yang akan memberikan nilai tertinggi untuk setiap pengeluaran uang mereka

c. Kunci keberhasilan perusahaan adalah meningkatkan nilai produk yang dihasilkan dengan meningkatkan produk berkualitas baik.

\section{Kualitas Produk}

Pengertian kualitas menurut Goetch dan Davis, Kualitas adalah suatu kondisi dinamis yang berkaitan dengan produk, pelayanan, orang, proses, dan lingkungan yang memenuhi atau melebihi apa yang diharapkan.

Dalam ISO 8402 dan SNI (Standar Nasional Indonesia), Pengertian kualitas adalah keseluruhan ciri dan karakteristik produk atau jasa yang kemampuannya dapat memuaskan 
kebutuhan, baik yang dinyatakan secara tegas maupun tersamar. Istilah kebutuhan diartikan sebagai spesifikasi yang tercantum dalam kontrak maupun kriteria-kriteria yang harus didefinisikan terlebih dahulu.

Menurut Deming, tujuan kualitas yaitu untuk memenuhi kebutuhan pelanggan yang sekarang dan di masa depan.

Scherkenbach mengatakan bahwa kualitas ditentukan oleh pelanggan, pelanggan menginginkan produk dan jasa yang sesuai dengan kebutuhan dan harapannya pada suatu tingkat harga tertentu yang menunjukkan nilai produk tersebut.

Istilah kualitas memang tidak terlepas dari manajemen kualitas yang mempelajari setiap era dari manajemen operasi dari perencanaan lini produk dan fasilitas, sampai penjadwalan dan memonitor hasil. Kualitas merupakan bagian dari semua fungsi usaha yang lain (pemasaran, sumber daya manusia, keuangan dan lain-lain). Dalam kenyataannya, penyelidikan kualitas adalah suatu penyebab umum yang alamiah untuk mempersatukan fungsi-fungsi usaha.

Selain itu, kualitas memerlukan suatu proses perbaikan yang terus menerus, yang dapat diukur, baik secara individual, organisasi, korporasi dan tujuan kinerja nasional. Dukungan manajemen, karyawan dan pemerintah untuk perbaikan kualitas adalah penting bagi kemampuan berkompetisi secara efektif di pasar global. Perbaikan kualitas lebih dari suatu strategi usaha, melainkan merupakan sumber penting kebanggaan nasional. Komitmen terhadap kualitas merupakan suatu sikap yang diformulasikan dan didemonstrasikan dalam setiap lingkup kegiatan dan kehidupan, serta mempunyai karakteristik hubungan yang paling dekat dengan anggota masyarakat.

\section{Pengendalian Kualitas Produk}

Menurut Vincent Gasperz (2005:480), pengendalian adalah: Control can mean an evaluation to indicate needed corrective responses, the act guiding, or the state of process in which the variability is attribute to a constant system of chance courses.

Jadi pengendalian dapat diartikan sebagai kegiatan yang dilakukan untuk memantau aktivitas dan memastikan kinerja sebenarnya yang dilakukan telah sesuai dengan yang direncanakan. Selanjutnya pengertian pengendalian kualitas dalam arti menyeluruh adalah sebagai berikut : tujuan utama pengendalian kualitas adalah untuk mendapatkan jaminan bahwa kualitas produk atau jasa yang dihasilkan sesuai dengan standar kualitas yang telah ditetapkan dengan mengeluarkan biaya yang ekonomis atau serendah mungkin.

Pengendalian kualitas tidak dapat dilepaskan dari pengendalian produksi, karena pengendalian kualitas merupakan bagian dari pengendalian produksi. Pengendalian produksi baik secara kualitas maupun kuantitas merupakan kegiatan yang sangat penting dalam suatu perusahaan. Hal ini disebabkan karena semua kegiatan produksi yang dilaksanakan akan dikendalikan, supaya barang dan jasa yang dihasilkan sesuai dengan rencana yang telah ditetapkan, dimana penyimpangan-penyimpangan yang terjadi diusahakan serendah-rendahnya.

Pengendalian kualitas juga menjamin barang atau jasa yang dihasilkan dapat dipertanggungjawabkan seperti halnya pada pengendalian produksi. Dengan demikian antara pengendalian produksi dan pengendalian kualitas erat kaitannya dalam pembuatan barang.

\section{Faktor-faktor Pengendalian Kualitas}

Menurut Douglas C. Montgomery (2001:26) dan berdasarkan beberapa literatur lain menyebutkan bahwa faktor-faktor yang mempengaruhi pengendalian kualitas yang dilakukan perusahaan adalah:

1. Kemampuan proses

Batas-batas yang ingin dicapai haruslah disesuaikan dengan kemampuan proses yang ada. Tidak ada gunanya mengendalikan suatu proses dalam batas-batas yang 
melebihi kemampuan atau kesanggupan proses yang ada.

2. Spesifikasi yang berlaku

Spesifikasi hasil produksi yang ingin dicapai harus dapat berlaku, bila ditinjau dari segi kemampuan proses dan keinginan atau kebutuhan konsumen yang ingin dicapai dari hasil produksi tersebut. Dalam hal ini haruslah dapat dipastikan dahulu apakah spesifikasi tersebut dapat berlaku dari kedua segi yang telah disebutkan di atas sebelum pengendalian kualitas pada proses dapat dimulai.

3. Tingkat ketidaksesuaian yang dapat diterima Tujuan dilakukan pengendalian suatu proses adalah dapat mengurangi produk yang berada di bawah standar seminimal mungkin. Tingkat pengendalian yang diberlakukan tergantung pada banyaknya produk yang berada di bawah standar yang dapat diterima.

4. Biaya kualitas

Biaya kualitas sangat mempengaruhi tingkat pengendalian kualitas dalam menghasilkan produk dimana biaya kualitas mempunyai hubungan yang positif dengan terciptanya produk yang berkualitas.

a. Biaya Pencegahan (Prevention Cost)

Biaya ini merupakan biaya yang terjadi untuk mencegah terjadinya kerusakan produk yang dihasilkan.

b. Biaya Deteksi/ Penilaian (Detection/ Appraisal Cost)

Adalah biaya yang timbul untuk menentukan apakah produk atau jasa yang dihasilkan telah sesuai dengan persyaratan-persyaratan kualitas sehingga dapat menghindari kesalahan dan kerusakan sepanjang proses produksi.

c. Biaya Kegagalan Internal (Internal Failure Cost)

Merupakan biaya yang terjadi karena adanya ketidaksesuaian dengan persyaratan dan terdeteksi sebelum barang atau jasa tersebut dikirim ke pihak luar (pelanggan atau konsumen). d. Biaya Kegagalan Eksternal (Eksternal Failure Cost)

Merupakan biaya yang terjadi karena produk atau jasa tidak sesuai dengan persyaratan-persyaratan yang diketahui setelah produk tersebut dikirimkan kepada para pelanggan atau konsumen.

\section{Tahapan Pengendalian Kualitas}

Untuk memperoleh hasil pengendalian kualitas yang efektif, maka pengendalian terhadap kualitas suatu produk dapat dilaksanakan dengan menggunakan teknik-teknik pengendalian kualitas, karena tidak semua hasil produksi sesuai dengan standar yang telah ditetapkan.

Menurut Suyadi Prawirosentono (2007;72), terdapat beberapa standar kualitas yang bisa ditentukan oleh perusahaan dalam upaya menjaga output barang hasil produksi diantaranya:

1. Standar kualitas bahan baku yang akan digunakan.

2. Standar kualitas proses produksi (mesin dan tenaga kerja yang melaksanakannya).

3. Standar kualitas barang setengah jadi.

4. Standar kualitas barang jadi.

5. Standar administrasi, pengepakan dan pengiriman produk akhir tersebut sampai ke tangan konsumen.

Dikarenakan kegiatan pengendalian kualitas sangatlah luas, untuk itu semua pengaruh terhadap kualitas harus dimasukkan dan diperhatikan. Secara umum menurut Suyadi Prawirosentono (2007;74), pengendalian atau pengawasan akan kualitas di suatu perusahaan manufaktur dilakukan secara bertahap meliputi hal-hal sebagai berikut:

1. Pemeriksaan dan pengawasan kualitas bahan mentah (bahan baku, bahan baku penolong dan sebagainya), kualitas bahan dalam proses dan kualitas produk jadi. Demikian pula standar jumlah dan komposisinya.

2. Pemeriksaan atas produk sebagai hasil proses pembuatan. Hal ini berlaku untuk barang setengah jadi maupun barang jadi. Pe- 
meriksaan yang dilakukan tersebut memberi gambaran apakah proses produksi berjalan seperti yang telah ditetapkan atau tidak.

3. Pemeriksaan cara pengepakan dan pengiriman barang ke konsumen.

4. Melakukan analisis fakta untuk mengetahui penyimpangan yang mungkin terjadi. Mesin, tenaga kerja dan fasilitas lainnya yang dipakai dalam proses produksi harus juga diawasi sesuai dengan standar kebutuhan. Apabila terjadi penyimpangan, harus segera dilakukan koreksi agar produk yang dihasilkan memenuhi standar yang direncanakan.

\section{Pengertian Perilaku Konsumen}

Perilaku konsumen pada hakikatnya untuk memahami "Mengapa konsumen melakukan dan apa yang mereka lakukan". Schiffman dan Kanuk (2008:6) mengemukakan bahwa studi perilaku konsumen adalah suatu studi mengenai bagaimana seorang individu membuat keputusan untuk mengalokasikan sumber daya yang tersedia (waktu, uang, usaha, dan energi). Konsumen memiliki keragaman yang menarik untuk dipelajari karena ia meliputi seluruh individu dari berbagai usia, latar belakang budaya, pendidikan, dan keadaan sosial ekonomi lainnya. Oleh karena itu, sangatlah penting untuk mempelajari bagaimana konsumen berperilaku dan faktor faktor apa saja yang mempengaruhi perilaku tersebut.

Definisi perilaku konsumen menurut Kotler dan Keller (2008:214). Perilaku konsumen adalah studi bagaimana individu, kelompok dan organisasi memilih, membeli, menggunakan dan menempatkan barang, jasa, ide atau pengalaman untuk memuaskan keinginan dan kebutuhan mereka.

Definisisi perilaku konsumen menurut Schiffman dan Kanuk (2008:6). Perilaku konsumen menggambarkan cara individu mengambil keputusan untuk memanfaatkan sumber daya mereka yang tersedia (waktu, uang, usaha) guna membeli barang-barang yang berhubungan dengan konsumsi.

Dari dua pengertian tentang perilaku konsumen di atas dapat diperoleh dua hal yang penting, yaitu: (1) sebagai kegiatan fisik dan (2) sebagai proses pengambilan keputusan. Berdasarkan beberapa definisi yang telah disebutkan di atas dapat disimpulkan bahwa perilaku konsumen adalah semua kegiatan, tindakan, serta proses psikologis yang mendorong tindakan tersebut pada saat sebelum membeli, ketika membeli, menggunakan, menghabiskan produk dan jasa setelah melakukan hal-hal di atas atau kegiatan mengevaluasi.

\section{Model Perilaku Konsumen}

Pemahaman terhadap perilaku konsumen bukanlah suatu hal yang mudah untuk dilakukan, karena terdapat banyak faktor yang berpengaruh dan saling interaksi satu sama lainnya, sehingga pendekatan pemasaran yang dilakukan oleh suatu perusahaan harus benar-benar dirancang sebaik mungkin dengan memperhatikan faktor-faktor tersebut. Selain itu, para pemasar harus mampu memahami konsumen, dan berusaha mempelajari bagaimana mereka berperilaku, bertindak dan berpikir. Walaupun konsumen memiliki berbagai macam perbedaan namun mereka juga memiliki banyak kesamaan.

Para pemasar wajib memahami keragaman dan kesamaan konsumen atau perilaku konsumen agar mereka mampu memasarkan produknya dengan baik. Para pemasar harus memahami mengapa dan bagaimana konsumen mengambil keputusan konsumsi, sehingga pemasar dapat merancang strategi pemasaran dengan lebih baik. Pemasar yang mengerti perilaku konsumen akan mampu memperkirakan bagaimana kecenderungan konsumen untuk bereaksi terhadap informasi yang diterimanya, sehingga pemasar dapat menyusun strategi pemasaran yang sesuai. Tidak dapat diragukan lagi bahwa pemasar yang memahami konsumen akan memiliki kemampuan bersaing yang lebih baik. 


\section{Faktor-Faktor yang Mempengaruhi Perilaku Konsumen}

Perilaku konsumen sangat dipengaruhi oleh keadaan dan situasi lapisan masyarakat di mana ia dilahirkan dan berkembang. Ini berarti konsumen berasal dari lapisan masyarakat atau lingkungan yang berbeda akan mempunyai penilaian, kebutuhan, pendapat, sikap, dan selera yang berbeda-beda, sehingga pengambilan keputusan dalam tahap pembelian akan dipengaruhi oleh beberapa faktor.

Faktor yang mempengaruhi perilaku konsumen menurut Kotler (2008:25) terdiri dari:

1. Faktor Kebudayaan. Faktor kebudayaan berpengaruh luas dan mendalam terhadap perilaku konsumen. Faktor kebudayaan terdiri dari: budaya, subbudaya, kelas sosial,

2. Faktor Sosial. Selain faktor budaya, perilaku seorang konsumen dipengaruhi oleh faktor-faktor sosial seperti kelompok acuan, keluarga serta status sosial.

3. Faktor Pribadi. Faktor pribadi yang memberikan kontribusi terhadap perilaku konsumen terdiri dari: usia dan tahap siklus hidup, pekerjaan dan lingkungan ekonomi, gaya hidup, kepribadian dan konsep diri.

4. Faktor Psikologis. Pilihan pembelian seseorang dipengaruhi oleh empat faktor psikologi utama yaitu motivasi, persepsi, pembelajaran, serta keyakinan dan pendirian.

\section{Teori Pengambilan Keputusan Thomas Saaty}

Pada dasarnya metode AHP yang dikembangkan oleh Thomas Saaty, memecahmecah suatu situasi ke dalam bagian-bagian komponennya dan menata bagian atau variabel ini ke dalam suatu susunan hirarki. Proses hirarki analisis memiliki prinsip dasar sebagai berikut:

1. Menyusun secara hirarkis, yaitu memecah persoalan menjadi unsur-unsur yang terpisah.
Pertama kita harus mendefinisikan situasi dengan seksama, memasukkan sebanyak mungkin rincian yang relevan, lalu menyusun model secara hirarki yang terdiri atas beberapa tingkat rincian, yaitu fokus masalah, kriteria, dan alternatif. Fokus masalah merupakan masalah utama yang perlu dicari solusinya dan terdiri hanya atas satu elemen yaitu sasaran menyeluruh. Selanjutnya, Kriteria merupakan aspek penting yang perlu dipertimbangkan dalam mengambil keputusan atas fokus masalah. Untuk suatu masalah yang kompleks atau berjenjang, kriteria dapat diturunkan kepada subsub kriteria. Dengan demikian kriteria bisa terdiri lebih dari satu tingkat hirarki. Yang terakhir adalah Alternatif, merupakan berbagai tindakan akhir dan merupakan pilihan keputusan dari penyelesaian masalah yang dihadapi.

2. Menetapkan prioritas, yaitu menentukan peringkat elemen-elemen menurut relatif pentingnya. Setelah menyusun hirarki, selanjutnya memberikan penilaian tentang kepentingan relatif dua elemen pada suatu tingkat tertentu dalam kaitannya dengan tingkat diatasnya. Penilaian ini merupakan inti dari AHP, karena ia akan berpengaruh terhadap prioritas elemen-elemen. Hasil penilaian ini lebih mudah dilihat bila disajikan dalam bentuk matriks (tabel) yang diberi nama matriks berpasangan (pairwise comparison). Pertanyaan yang biasa dilakukan dalam meyusun skala kepentingan adalah.

(1) Elemen mana yang lebih (penting/disukai/mungkin/...),

(2) Berapa kali lebih (penting/disukai/ mungkin/...)?

3. Mengukur konsistensi logis, yaitu menjamin bahwa semua elemen dikelompokkan secara logis dan diperingkatkan secara konsisten sesuai dengan kriteria yang logis. 
Proses AHP mencakup pengukuran konsistensi yaitu apakah pemberian nilai dalam pembandingan antar obyek telah dllakukan secara konsisten. Ketidakkonsistenan dapat timbul karena miskonsepsi atau ketidaktepatan dalam melakukan hirarki, kekurangan informasi, kekeliruan dalam penulisan angka, dan lain-lain. Salah satu contoh dalam inkonsistensi dalam matriks pembandingan ialah dalam menilai mutu suatu produk. Misalkan, dalam preferensisi pengambil keputusan, A 4x lebih baik dari B, B 3x lebih baik dari C, maka seharusnya A 12x lebih baik dari C. Tetapi jika dalam pemberian nilai, A diberi nilai $6 x$ lebih dari $\mathrm{C}$, berarti terjadi inkonsistensi.

Rasio konsistensi (consistency ratio, CR) menunjukkan sejauh mana analis konsisten dalam memberikan nilai pada matrik pembandingan. Secara umum, hasil analisis dianggap konsisten jika memiliki CR ? 10\%. Jika nilai CR $>10 \%$, perlu dipertimbangkan untuk melakukan reevaluasi dalam penyusunan matriks pembandingan.

\section{Teori Permintaan}

Banyak teori yang membahas tentang teori permintaan, karena permintaan sangat mempengaruhi jumlah output yang akan dihasilkan ketika harga bersifat kaku. Karena permintaan ini dapat mempengaruhi perekonomian jangka pendek. Para ahli ekonomi mempelajari teori permintaan dan faktor-faktor yang mempengaruhi permintaan, yang berguna dalam menstabilkan perekonomian jangka pendek (Mankiw, 2003).

Sifat hubungan antara suatu barang dengan harganya dalam hukum permintaan bersifat kebalikan atau negatif, artinya jika suatu barang naik, permintaan terhadap barang tersebut akan berkurang, dan sebaliknya jika harga suatu barang turun, permintaan barang tersebut akan meningkat.

Case dan Fair (2005), mengemukakan bahwa hukum permintaan yang hanya dipengaruhi oleh harga barang itu sendiri adalah menyesat- kan, karena hanya memusatkan pada harganya saja sebagai satu-satunya penentu permintaan (ceteris paribus). Permintaan adalah hubungan yang mulivariate, yaitu ditentukan oleh banyak faktor secara serentak. Beberapa faktor-faktor terpenting yang mempengaruhi permintaan adalah :

a. Harga barang itu sendiri

b. Harga barang lain atau pengganti

c. Pendapatan rumah tangga dan pendapatan rata-rata masyarakat

d. Jumlah penduduk

e. Corak distribusi pendapatan dalam masyarakat

f. Cita rasa masyarakat

g. Ramalan mengenai keadaan di masa yang akan datang

Permintaan pada dasarnnya mempunyai dua pengertian :

a. Permintaan yang bersifat potensial, yaitu jumlah absolut barang yang dibutuhkan.

b. Permintaan yang bersifat efektif, yaitu jumlah barang yang dibutuhkan konsumen dan didukung oleh kekuatan daya beli.

Fungsi permintaan berdasarkan pada teori permintaan adalah :

$\mathrm{Qx}=\mathrm{f}(\mathrm{Px}, \mathrm{Py}$, Qpend, Ymasyarakat , T, F $)$

Keterangan :

$\mathrm{Qx}=$ Jumlah barang yang diminta

$\mathrm{Px}=$ Harga barang itu sendiri

Py $=$ Harga barang lain

Qpend = Jumlah penduduk

Ymasyarakat $=$ Pendapatan rata-rata msyarakat atau per kapita

$\mathrm{T}=$ Cita rasa masyarakat

$\mathrm{F}=$ Ramalan mengenai keadaan dimasa yang akandating

1. Harga barang itu sendiri

Hukum permintaan pada dasarnya merupakan suatu hipotesis yang menyatakan: "Semakin rendah harga suatu barang maka semakin banyak permintaan terhadap barang tersebut. Sebaliknya, semakin tinggi harga suatu barang maka semakin sedikit 
permintaan terhadap barang tersebut" (ceteris paribus).

Harga barang yang lebih murah akan menarik minat masyarakat untuk membeli barang tersebut dibandingkan membeli barang sejenisnya dengan harga yang lebih tinggi, selain itu turunnya atau lebih murah nya harga suatu barang akan menyebabkan pendapatan riil pembeli bertambah.

2. Harga barang-barang lain

Permintaan konsumen dapat dipengaruhi oleh harga, harga barang yang akan dibeli $(\mathrm{P})$, harga barang pengganti (price of subsitution product) maupun harga pelengkap (price of complementary product). Konsumen akan membatasi pembelian jumlah barang yang diinginkan apabila harga barang terlalu tinggi, bahkan ada kemungkinan konsumen memindahkan konsumsi dan pembeliannya kepada barang pengganti (barang substitusi) yang lebih murah harganya. Harga barang pelengkap juga akan mempengaruhi keputusan seorang konsumen untuk membeli atau tidak barang utamanya, bila permintaan barang utama meningkat, maka permintaan akan barang penggantinya akan menurun dan sebaliknya.

Hubungan antara suatu barang dengan berbagai jenis-jenis barang lainnya dapat dibedakan menjadi tiga golongan :

a. Barang lain merupakan barang pengganti.

Suatu barang dinamakan sebagai barang pengganti kepada barang lain apabila ia dapat menggantikan fungsi barang lain tersebut. Harga barang pengganti dapat mempengaruhi permintaan barang yang dapat digantikannya. Jika harga barang pengganti bertambah murah maka, barang yang digantikannya akan mengalami pengurangan dalam permintaannya. Oleh sebab itu, barang pengganti ini sering kita sebut dengan barang substitusi. b. Barang lain merupakan barang pelengkap.

Apabila suatu barang selalu digunakan bersama dengan barang lainnya, maka barang tersebut dinamakan barang pelengkap kepada barang lainnya tersebut. Kenaikan atau penurunan permintaan terhadap barang pelengkap selalu berjalan dengan perubahan permintaan barang yang digenapinya. Oleh sebab itu, barang pelengkap ini sering kita sebut dengan barang komplemen.

Kedua barang itu tidak memiliki keterkaitan sama sekali antar satu dengan yang lain. Apabila dua macam barang tidak mempunyai hubungan yang penting, maka perubahan terhadap permintaan salah satu barang tersebut tidak akan mempengaruhi permintaan barang lainnya. Barang seperti itu dinamakan barang netral.

3. Pendapatan rata-rata masyarakat (Pendapatan Per Kapita).

Pendapatan para pembeli merupakan faktor yang sangat penting dalam menentukan permintaan terhadap berbagai barang. Kosumen tidak akan dapat melakukan pembelanjaan barang kebutuhan apabila pendapatan tidak ada atau tidak memadai. Dengan demikian, maka perubahan pendapatan akan mendorong konsumen untuk mengubah permintaan akan barang kebutuhannya. Berdasarkan pada sifat perubahan permintaan yang berlaku apabila pendapatan berubah, berbagai barang dapat dibedakan menjadi empat golongan :

4. Jumlah penduduk.

Pertambahan penduduk tidak dengan sendirinya menyebabkan pertambahan permintaan. Tetapi, biasanya pertambahan penduduk diikuti oleh perkembangan dalam kesempatan kerja. Dengan demikian lebih banyak orang yang menerima pen- 
dapatan dan ini akan menambah daya beli dalam masyarakat untuk berbelanja. Pertambahan daya beli masyarakat ini akan menambah permintaan.

5. Nilai Guna (Utility).

Suatu barang dikatakan mempunyai nilai guna apabila ia dapat memenuhi kebutuhan manusia. Seseorang meminta barang tertentu karena kepuasan atau utilitas yang didapatkan dari mengkonsumsi barang tersebut. Semakin banyak barang yang dikonsumsi maka semakin besar nilai guna yang diperoleh sampai pada titik tertentu. Ada dua konsep mendasar mengenai nilai guna, konsep pertama menyebutkan bahwa nilai guna bisa diukur atau diberikan nilai angka tertentu. Konsep kedua menyebutkan bahwa nilai guna suatu benda tidak dapat dihitung.

\section{METODELOGI PENELITIAN}

Metode penelitian yang digunakan untuk keperluan menganalisa data dalam penelitian ini adalah sebagai berikut:

\section{Metode Pengumpulan Data}

Dalam mengumpulkan data digunakan sumber data, adapun sumber data yang diperoleh yaitu:

1. Data Primer

Data yang diperoleh langsung oleh peneliti melalui kuesioner di lapangan

2. Data Sekunder

Data yang dikumpulkan atau diperoleh melalui sumber-sumber yang ada, diperoleh dari:

a. Laporan-laporan yang dikeluarkan oleh PT. Tridaya Eka Semesta, misalnya data bahan baku, data bahan yang ditolak, data produksi, data pengiriman dan data mur spesial yang ditolak oleh konsumen

b. Refrensi lain, seperti buku, sekreipsi, tesis dan desertasi lain yang berhubungan dengan penelitian ini.

\section{Teknik Pengumpulan Data}

Kuisioner; membuat dan menyebar pertanyaan yang berhubungan dengan Prefensi konsumen tehadap produk mur spesial dengan membandingkan faktor-faktor yang menurut responden lebih dominan antara satu faktor terhadap faktor lain. Responden diambil berdasarkan data personal yang dipilih oleh PT. Tridaya Eka Semesta bekerja sebagai konsumen atau pembeli (purchaser), quality control, gudang penerimaan barang dan bagian produksi.

\section{Teknik pengolahan Data}

1. Editing adalah pengecekan atau pengoreksian data yang sudah dikumpulkan di lapangan, karena ada data yang masuk tidak logis atau meragukan

2. Coding

Pemberian atau pembuatan kode-kode pada tiap-tiap data yang termasuk ke dalam kategori yang sama

3. Tabulating

Pembuatan tabel-tabel yang berisikan data yang telah diberi kode sesuai analisis yang dibutuhkan.

\section{Teknik Analisa Data}

Analisa data dilakukan dengan menggunakan Anatical Hierarchy Process (AHP) Thomas Saaty, 
$\mathrm{Hl}$

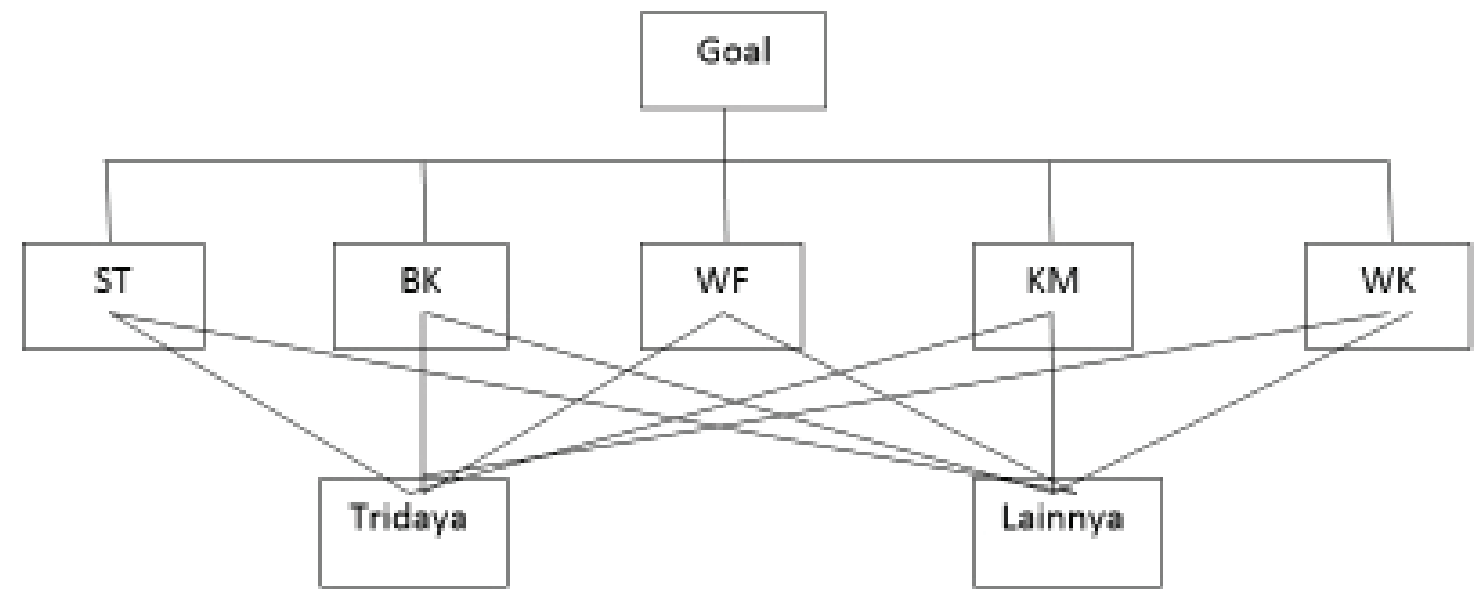

Dan dikonstruksikan sebagai berikut: dengan menggunakan software (program pengolah data) expert choice.

Keterangan:

ST : Kesesuaian Spesifikasi Teknik Mur

BK : Bahan Baku

WF : Wujud Fisik

KM : Kemasan

WK : Waktu Pengiriman

Tridaya : Mur Hasil Produksi PT. Tridaya Eka Semesta

Lainnya : Mur Produksi Kompetiter

Kuesioner didesain dengan bentuk pertanyaan untuk menyaring jawaban responden guna memenuhi penilaian perbandingan berpasangan yang disusun dalam bentuk matrik, dimana sel-sel tersebut adalah: ST, BK, WF, KM, dan WK sevara berpasangan. Pertanyaan dalam kuisioner harus dapat menjaring sehingga peneliti dapat melengkapi sel-sel berpasangan seperti di dalam tabel di bawah ini:

\begin{tabular}{|l|l|c|c|c|l|l|} 
GOAL & ST & BK & WF & KM & WK & $\begin{array}{l}\text { Eigen Vector } \\
\text { Bobot } \\
\text { Pengaruh }\end{array}$ \\
\hline ST & 1 & & & & \\
BK & & 1 & & & \\
WF & & & 1 & & \\
KM & & & & 1 & & \\
WK & & & & & 1 & \\
\hline
\end{tabular}

HASIL PENELITIAN

Faktor-faktor Yang Mempengaruhi Pemilihan Mur Spesial

Sebagai jawaban pertama atas jawaban penelitian, penulis melakukan perhitungan dengan terlebih dahulu melakukan penentuan atas keriteria yang menjadi faktor penentu dalam memilih mur spesial. Kriteria-kriteria tersebut, yang dimasukan adalah 5 prioritas tertinggi berdasarkan permintaan konsumen, adalah:

a. Kesesuaian Spesifikasi Teknik (As Building)/ST

b. Bahan Baku (Raw Material) /BK

c. Wujud Fisik (Physical) /WF

d. Kemasan (Packing)/KM

e. Waktu Pengiriman (Delivery)/WK

Sedangkan produk yang akan dibandingkan adalah produk yang dihasilkan oleh PT. Tridaya Esa Semesta (TR) dengan produk yang dihasilkan oleh perusahaan lain PT. Inter (IT).

Faktor tersebut di atas dianalisa dengan menggunakan perhitungan matrik berpasangan adalah sebagai berikut:

\begin{tabular}{|l|l|l|l|l|l|l|}
\hline GOAL & ST & BK & WF & KM & WK & $\begin{array}{l}\text { Eigen Vector } \\
\text { Bobot } \\
\text { Pengaruh }\end{array}$ \\
\hline ST & 1 & 1,2 & 3,1 & 4,6 & 4,6 & 0,354 \\
BK & & 1 & 7,8 & 4,7 & 4,5 & 0,375 \\
WF & & & 1 & 3,1 & 3,2 & 0,142 \\
KM & & & & 1 & 1,2 & 0,066 \\
WK & & & & & 1 & 0,062 \\
\hline
\end{tabular}


Dari hasil perhitungan matrik berpasangan menunjukan :

1. Bahan Baku (Raw Material) $/ \mathrm{BK}=37,5 \%$

2. Kesesuaian Spesifikasi Teknik (As Building) $/ \mathrm{ST}=35,4 \%$

3. Wujud Fisik (Physical) /WF $=14,2 \%$

4. Kemasan (Packing) $/ \mathrm{KM}=06,6 \%$

5. Waktu Pengiriman (Delivery) $/ \mathrm{WK}=$ $06,2 \%$

Kumpulan data kuesioner dari beberapa konsumen yang diolah dengan menggunakan AHP (Analitical Hirarcy Process) Thomas Saaty dengan bantuan software expert choice diperoleh informasi bahwa faktor bahan baku (BK) menjadi prioritas utama konsumen dalam menentukan kualitas mur spesial dengan bobot 37,50 \% kesesuaian spesifikasi teknis (ST) menjadi prioritas kedua dengan bobot 35,40 \% wujud fisik (WF) dengan bobot 14,20\% menjadi prioritas ketiga kemasan (KM) dengan bobot $6,6 \%$ dan yang menjadi prioritas terrendah adalah waktu pengiriman (WK) dengan bobot $6,2 \%$. Tingkat konsistensi responden (ICR) adalah sebesar $4 \%$ karena angka yang ditunjukan di bawah $10 \%$ maka penilaian atas pembobotan tersebut dianggap konsisten.

\section{Analisis Terhadap Pilihan Merek Mur Spesial}

Menjawab tujuan penelitian ke dua, peneliti melakukan analisis dengan cara membandingkan antara faktor yang menjadi prioritas pilihan dengan merek lain dengan prioritas sama. Merek yang diteliti adalah merek Tridaya dan merek Inter.

Dengan membandingkan dua merek tersebut berdasarkan kesesuaian spesifikasi teknis, maka didapatkan bahwa:

\begin{tabular}{|l|l|l|l|} 
GOAL & TR & IT & $\begin{array}{l}\text { Eigen Vector } \\
\text { Bobot Pengaruh }\end{array}$ \\
\hline TR & 1 & 3,1 & 0,756 \\
IT & & 1 & 0,244 \\
\hline
\end{tabular}

$$
\begin{array}{ll}
\text { Menujukan bahwa } & \\
\text { Merek Tridaya } & =75,6 \% \\
\text { Merek Inter } & =24,4 \%
\end{array}
$$

Hal ini menujukan bahwa jika kesesuaian spesifikasi teknis yang diambil sebagai acuan maka konsumen lebih memilih merek Tridaya sebagai prioritas pilihan dengan bobot $75,6 \%$ sedangkan merek Inter dengan bobot $24,4 \%$.

Dengan membandingkan dua merek tersebut berdasarkan Bahan Baku, maka akan didapatkan bahwa:

\begin{tabular}{|l|l|l|l|}
\hline GOAL & TR & IT & $\begin{array}{l}\text { Eigen Vector } \\
\text { Bobot Pengaruh }\end{array}$ \\
\hline TR & 1 & 2,9 & 0,744 \\
IT & & 1 & 0,256 \\
\hline \multicolumn{3}{c}{ ICR $=0$}
\end{tabular}

Menujukan bahwa

$$
\begin{array}{ll}
\text { Merek Tridaya } & =74,4 \% \\
\text { Merek Inter } & =25,6 \%
\end{array}
$$

Hal ini menujukan bahwa jika bahan baku yang diambil sebagai acuan maka konsumen lebih memilih merek Tridaya sebagai prioritas pilihan dengan bobot $74,4 \%$ sedangkan merek Inter dengan bobot $25,6 \%$.

Dengan membandingkan dua merek tersebut berdasarkan wujud fisik, maka akan didapatkan bahwa:

\begin{tabular}{|l|l|l|l|}
\hline GOAL & TR & IT & $\begin{array}{l}\text { Eigen Vector } \\
\text { Bobot Pengaruh }\end{array}$ \\
\hline TR & 1 & 3,1 & 0,756 \\
IT & & 1 & 0,244 \\
\hline
\end{tabular}

$$
\mathrm{ICR}=0
$$

Menujukan bahwa

$\begin{array}{ll}\text { Merek Tridaya } & =75,6 \% \\ \text { Merek Inter } & =24,4 \%\end{array}$

Hal ini menujukan bahwa jika wujud fisik yang diambil sebagai acuan maka konsumen lebih memilih merek Tridaya sebagai prioritas pilihan dengan bobot 75,6 \% sedangkan merek Inter dengan bobot $24,4 \%$. 
Dengan membandingkan dua merek tersebut berdasarkan kemasan, maka akan didapatkan bahwa:

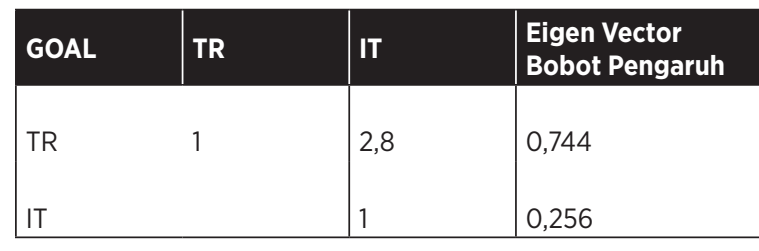

\begin{tabular}{ll}
\multicolumn{2}{c}{$I C R=0$} \\
Menujukan bahwa & \\
Merek Tridaya & $=74,4 \%$ \\
Merek Inter & $=25,6 \%$
\end{tabular}

Hal ini menujukan bahwa jika kemasan yang diambil sebagai acuan maka konsumen lebih memilih merek Tridaya sebagai prioritas pilihan dengan bobot $74,4 \%$ sedangkan merek Inter dengan bobot $25,6 \%$.

Dengan membandingkan dua merek tersebut berdasarkan waktu pengiriman, maka akan didapatkan bahwa:

\begin{tabular}{|l|l|l|l|}
\hline GOAL & TR & IT & $\begin{array}{l}\text { Eigen Vector } \\
\text { Bobot Pengaruh }\end{array}$ \\
\hline TR & 1 & 3,5 & 0,778 \\
IT & 1 & 0,222 \\
\hline \multicolumn{3}{c}{ ICR $=0$} \\
\multicolumn{3}{c}{ Menujukan bahwa } \\
Merek Tridaya \\
Merek Inter & $=77,8 \%$ \\
\end{tabular}

Hal ini menujukan bahwa jika kemasan yang diambil sebagai acuan maka konsumen lebih memilih merek Tridaya sebagai prioritas pilihan dengan bobot $77,8 \%$ sedangkan merek Inter dengan bobot $22,2 \%$.

Secara keseluruhan besarnya pemilihan bobot pilihan terhadap permintaan mur spesial dengan melakukan sintesa prioritas menggunakan software expert choice, diperoleh hasil sebagai berikut:

$\begin{array}{ll}\text { Tridaya } & 75,1 \% \\ \text { Inter } & 24,9 \%\end{array}$

Hal ini dapat disimpulkan bahwa mur produksi PT. Tridaya Eka Semesta menempati pilihan pertama dengan bobot $75,1 \%$ dan inter menempati urutan kedua dengan bobot $24,9 \%$.

\section{Analisis Sensitifitas}

Analisis sensitifitas masing-masing faktor pengaruhnya terhadap perubahan bobot pilihan terhadap mur spesial adalah:

1. Jika faktor bahan baku dinaikan menjadi 75 $\%$ maka bobot pilihan terhadap mur spesial Tridaya akan menurun menjadi $74,7 \%$

2. Jika faktor wujud fisik dinaikan menjadi 50 $\%$ maka bobot pilihan terhadap mur spesial Tridaya akan naik menjadi $75,3 \%$

3. Jika faktor kemasan dinaikan menjadi $40 \%$ maka bobot pilihan terhadap mur spesial Tridaya akan menurun menjadi $74,6 \%$

4. Jika faktor waktu pengiriman dinaikan menjadi $30 \%$ maka bobot pilihan terhadap mur spesial Tridaya akan naik menjadi $75,8 \%$

\section{KESIMPULAN}

Dari hasil analisa maka dapat ditarik kesimpulan sebagai berikut:

1. Faktor bahan baku menjadi prioritas utama perusahaan perakit spare part sepeda motor dalam menentukan pilihan terhadap mur spesial. Ditunjukan dalam pendapatan bobot $37,50 \%$ diikuti oleh kesesuaian spesifikasi teknis (ST) menjadi prioritas kedua dengan bobot 35,40 \% wujud fisik (WF) dengan bobot 14,20\% menjadi prioritas ketiga kemasan (KM) dengan bobot $6,6 \%$ dan yang menjadi prioritas terrendah adalah waktu pengiriman (WK) dengan bobot 6,2 \% . Tingkat konsistensi responden (ICR) adalah sebesar $4 \%$, maka penilaian atas pembobotan tersebut dianggap konsisten karena angka yang ditunjukan mensyaratkan di bawah $10 \%$.

2. Perbandingan antara dua merek yang menjadi pemasok mur spesial, yaitu Tridaya 
dan Inter. Terlihat bahwa Tridaya mampu memenangkan persaingan dengan bobot sebesar 75,1 \% sedangkan kompetitor Inter menempati urutan berikutnya dengan bobot $24,9 \%$.

3. Analisis sensitifitas adalah:

Faktor bahan baku jika dinaikan menjadi $75 \%$ maka bobot pilihan terhadap mur spesial Tridaya berubah dari 75,1 $\%$ menjadi $74,7 \%$ (menurun sebesar 0,4 $\%)$. Jika faktor wujud fisik dinaikan menjadi $50 \%$ maka bobot pilihan terhadap mur spesial Tridaya berubah dari 75,1 $\%$ menjadi $75,3 \%$ (naik sebesar $0,2 \%$ ). Jika faktor kemasan dinaikan menjadi 40 $\%$ maka bobot pilihan terhadap mur spesial Tridaya berubah dari $75,1 \%$ menjadi $74,6 \%$ (menurun menjadi $0,5 \%$ ). Sedangkan jika faktor waktu pengiriman dinaikan menjadi $30 \%$ maka bobot pilihan terhadap mur spesial Tridaya berubah dari 75,1 \% menjadi 75,8 \% (akan naik sebesar $0,7 \%)$. Faktor yang berpengaruh positif terhadap merek Tridaya adalah wujud fisik dan waktu pengiriman. Karena dengan dinaikannya bobot, dua faktor ini akan berpengaruh positif terhadap prefensi konsumen terhadap permintaan mur spesial merek Tridaya. Sebaliknya faktor peningkatan bahan baku dn kemasan berpengaruh positif terhadap prefensi konsumen terhadap perusahaan kompetiter (Inter).

\section{SARAN}

1. Untuk mempertahankan posisi Tridaya dalam mempertahankan pasar, maka yang perlu diperhatikan adalah menitikberatkan pada perhatian pada wujud fisik dan waktu pengiriman produk, karena dengan kenaikan bobot kedua faktor tersebut, dapat meningkatkan bobot prefrensi konsumen terhadap permintaan mur spesial PT. Tridaya. Tetap mempertahankan kesesuaian spesifikasi teknis, bahan baku, dan kemasan harus tetap dilakukan agar hubungan bisnis yang telah terjalin tetap terjaga.

2. Mencari pasar baru serta meningkatkan kapasitas produksi untuk meningkatkan perputaran omset perusahaan dalam meningkatkan keuntungan usaha.

\section{DAFTAR PUSTAKA}

Arikunto S, 2000, Manajemen Penelitian, Rieneka Cipta, Jakarta

Dorothea Wahu Ariani, 2004, Pengendalian Kualitas Statistik (Pendekatan Kuantitatif dalam Manajemen Kualitas), Penerbit CV Andi Offset : Yogyakarta.

Gasperz, Vincent, 2005, Total Quality Management, PT. Gramedia Pustaka Utama. Jakarta

Kotler dan Keller, 2006, Manajemen Pemasaran, Jilid 1, Erlanggra, Jakarta

Kotler, P. 2003 Manajemen Pemasaran: Analisis, Perencanaan, Implementasi dan Control. Edisi revisi, PT. Prenhalindo, Jakarta

Kotler, P. dan Garry Amstrong. 2001, Prinsipprinsip Pemasaran, Edisi revisi. Erlangga. Jakarta

Kotler, P. 2000, “Marketing Manajemen”, Intenasional Edision

Montgomery, Douglas C. 2001. Introduction to Statistical Quality Control. 4th Edition. New York: John Wiley \& Sons, Inc. United States of Amerika

Payne. A. 2000, The Esence Of Service Marketing.Pemasaran Jasa, Andi Publiser, Yogyakarta

Prawirosentono, Suyadi. 2007, Filosofi Baru Tentang Manajemen Mutu Terpadu Abad 21 "Kiat Membangun Bisnis Kompetitif", Jakarta : Bumi Aksara.

Rangkuti, P. 2003, Maesturing Customer Satisfaction, Teknik Megukur dan Strategi Meningkatkan Kepuasan Pelanggan Plus Analisis kasus PLN, JP. PT. Geramedia Utama, Jakarta 
Saaty, TL. 1992. "New Perspectives on Decision Making in Complex Environment", Pengantar Belajar, SEI Center for Advanced Studies in Management, The Wharton School of the University of Pennsylpania.

Saaty, Thomas L. and Kirti Penawati, 1996 "The Analitic Hieracy Process and Linier Programing in Human Resourse Allocation".

Sugiono, 2012, Metode Penelitian Bisnis, CV. Alfabet, Bandung

Sugiono, 2003, Statistik Non Parametris untuk Penelitian CV. Alfabet. Bandung

Supranto, J. 2001, Pegukuran Tungkat Kepuasan Pelanggan: untuk Menaikkan Pangsa Pasar, Rineka Cipta, Jakarta

Tjiptono,F, 2000, Manajemen Jasa, Andi Yogyakarta.

Tjiptono,F, 2002, Prinsip-prinsip Total Quality Service, Andi Jogjakarta.

Tjiptono,F,A. Diana, 2001, Total Qualiti Management, Andi Jogjakarta.

Umar, H. 2003, Metode Penelitian, PT. Gramedia Pustaka Utama, Jakarta.

Zaithaml, V.A and Bitner, M.J., 2000, Service Marketing, The Machgraw Hill Companies, Inc, New York. 